\title{
Carbon footprint from helitankers: sustainable decision making in aerial wildfire fighting
}

\author{
Sergio Alvarez , Rosa Planelles and Agustín Rubio
}

\begin{abstract}
Carbon footprint (CF) can be a key factor stimulating innovation while driving sustainable decision making. The air transport sector and wildfires are considered to be relevant contributors to greenhouse gas emissions. Among the available resources for wildfire suppression, aerial firefighting - particularly using helitankers - is the most effective method. However the high economic costs and fuel-related emissions incurred by helitankers prevent their widespread use. This work aims to calculate the CF from helitankers in order to assess this new indicator for sustainable decision making. The CF is calculated here by a compound method based on the financial accounts of a Spanish company that owns 20 helitankers. The total cumulative corporate $\mathrm{CF}$ in 2012 was $5497 \mathrm{t} \mathrm{CO}_{2}$ equivalents. We discuss the influence of the method, its implications and future actions for the reduction of greenhouse gas emissions. Our experience should be considered as a pilot study providing further evidence of the value of using sustainable indicators in decision making.
\end{abstract}

Additional keywords: Carbonfeel, consumption-based emissions, environmental accounting, helicopters, MC3, Scope 3 emissions.

\section{Introduction}

Climate change is a matter of major concern to modern society (Solomon et al. 2007). The increase in greenhouse gas (GHG) emissions is clearly having an effect on climate systems (Stocker et al. 2013), with potential negative feedback for the health of ecosystems (Butchart et al. 2010). Forest ecosystems particularly play a crucial role in this global carbon (C) cycle, acting as a net $\mathrm{C}$ sink and storing between 40 and $60 \%$ of all terrestrial $\mathrm{C}$, including $\mathrm{C}$ stored in vegetation and soil organic matter (Körner 2005; Fischlin et al. 2007; Bonan 2008; Pan et al. 2011).

In this context, the goal of sustainable development must be pursued through the use of new environmental sustainability indicators (Roca and Searcy 2012), and particularly the carbon footprint (CF) (Wiedmann and Minx 2008; Peters 2010). The target of reducing CF could be a key factor stimulating innovation while driving sustainable decision making. CF is an active research topic with a large number of initiatives currently underway in several countries (Wiedmann et al. 2011). Current methodological advantages in hybrid approaches allow CF to be implemented in a wide range of businesses and products (Suh and Lippiatt 2012); however, its effectiveness as a new approach to drive sustainable decision making is still under study (Majeau-Bettez et al. 2011). There is a need for further research to demonstrate the feasibility of these new sustainable indicators in decision making. Positive results for early adopters may lead to future regulation and consumer trust.

The aviation sector is today regarded as a key contributor to GHG emissions (Peters et al. 2007). This importance has led to the inclusion in the European Union's Emission Trading Scheme (Miyoshi 2014) of commercial aviation, the only part of the aviation sector for which emissions information is officially recorded and discussed. In the global context, the International Civil Aviation Organisation has agreed to develop by 2016 a specific global market-based mechanism to be implemented in international aviation by 2020 (Barbot et al. 2014). A review of the literature reveals several reports of helicopter emissions from fuel consumption (FOCA 2009; Linares Bejarano 2011; Merkisz et al. 2012; Grogan 2013), although few consider emissions from other sources such as maintenance or construction (Ricondo and Associates 2008). This increased concern reinforces the need to consider all available strategies for 
sustainable development, such as the implementation of $\mathrm{CF}$ in decision making.

Another major source of emissions is wildfires. Fire has influenced $\mathrm{C}$ cycling and interacted with the climate system for the $\sim 420$ million years of Earth's history (Bowman et al. 2009). Wildfires spread rapidly in the Mediterranean climate owing to the generally hot dry conditions, and the interaction between human activity and nature has made them a major economic, social and ecological problem. Climate change is likely to increase the intensity and frequency of drought in many of these Mediterranean areas, creating more intense and frequent wildfires (Flannigan et al. 2006; Sommers et al. 2014). A comprehensive knowledge of fire emissions has been promoted to effectively quantify and assess the role of fire in the $\mathrm{C}$ cycle, and the long-term benefits of carbon sequestration projects (Meigs et al. 2011; Miller et al. 2012). This knowledge could be improved with the assessment of emissions from human prevention, detection and suppression strategies.

Wildfire prevention, detection and suppression strategies are the ongoing subject of evaluation and discussion. Fast and effective detection is a key factor in wildfire fighting (Ambrosia et al. 1998), and once a fire is detected, wildfire suppression becomes critical. Suppression methods vary among countries according to their technological capacity (Moore et al. 2003). Although a large number of factors determine the success and effectiveness of the method, aerial firefighting is considered the most successful strategy thanks to its capacity for rapid deployment (Grigel 1974). Of the available aerial firefighting resources, helitankers are particularly valuable due to their ability to (1) transport both firefighting brigades and buckets; (2) reach areas that are difficult or impossible to access by land; (3) refill buckets in small areas in lakes, rivers, reservoirs or portable tanks; (4) evacuate humans at risk, and above all; (5) deliver a swift initial strike to gain early control and reduce the risk of large wildfires. Despite these positive features, helitankers' high fuel and maintenance costs hinder their widespread use. Increasing environmental concerns about aviation emissions may lead to their consideration as unsustainable from an environmental perspective.

This work aims to calculate the CF from helitankers in order to assess this new indicator for sustainable decision making. Our experience should be considered as a pilot study to assess the feasibility of $\mathrm{CF}$ in decision making.

\section{Materials and methods}

Helitanker CF is calculated using a compound method based on financial accounts (or MC3, from its Spanish acronym 'Método Compuesto de las Cuentas Contables') (Doménech 2007). MC3 is a tiered hybrid analysis (Suh and Huppes 2005) capable of including both product and corporate $\mathrm{CF}$ in a comprehensive assessment (Carballo-Penela and Doménech 2010; Alvarez et al. 2015). This method is one of the most widely accepted approaches in Spain, and has been approved as a valid means of assessing corporate CF within the framework of the Spanish Voluntary GHG Reduction Agreement (De la Cruz Leiva et al. 2011). It is also endorsed by the Spanish Technical Committee of the Carbonfeel Initiative (Carbonfeel 2014). The results can be certified under international standards for both products and companies (ISO 2013a, b). Advances in MC3 have been the subject of previous studies (Penela 2008; Carballo-Penela and Doménech 2010; Cagiao et al. 2011, 2012; Alvarez et al. 2014, 2015; Alvarez and Rubio 2015a, b), and this study applies the latest 2012 version (v. 12.3) developed within the Carbonfeel Initiative (Carbonfeel 2013). For a complete description of the process and methodological issues, see Carballo-Penela (2010) and Cagiao et al. (2012).

MC3 involves assessment through comprehensive corporate inventories and allows the inclusion of other indirect emissions (ISO 2006), also known as Scope 3 emissions (Greenhalgh et al. 2010). For example, these emissions correspond to the ones associated with the life cycle of kerosene and purchased materials such as oils and transport replacements. MC3 also enables the use of boundaries and thresholds that are unlikely to vary subjectively with each analyst - a critical factor when comparing results (Alvarez et al. 2014). Helitanker CF is calculated through the specific analysis of one Spanish company ('Hispánica de Aviación SA', hereafter HASA), with over 25 years' experience in helicopter services and specialising in helitankers for aerial firefighting. Currently, HASA owns 20 helicopters (15 are in operation) and is one of the largest contractors for aerial firefighting in Spain, in addition to operating in other countries in Europe and South America. Its operations comprise the airfield 'El Tiétar' (4.0 ha) located in the municipality of La Iglesuela (Toledo province, central Spain); the helibase ' $\mathrm{La}$ Guancha' (0.4 ha) located in La Guancha (Tenerife province, Canary Islands); and its administrative offices ( 0.2 ha) located in Pozuelo de Alarcón (Madrid province, central Spain). The boundaries of the analysis are defined in terms of (1) physical boundaries (area controlled by HASA), (2) organisational boundaries (operations directly controlled by HASA) and (3) operational boundaries (divided into four management areas: (a) Helitanker maintenance, (b) Helitanker operations, (c) Airfield and helibase, and (d) General administration). Detailed consumption and financial data from 2012 are classified into three main inventories: (1) land-use inventory -owned or controlled land area classified into the five main categories defined by the Eggleston et al. (2006a), (2) waste inventory -all residues produced in tons, classified according to the Commission Decision (2000)-, and (3) consumption inventory-fuel and electricity consumption in physical units besides annual financial reports in $€$, both allocated to the consumption categories in MC3-. In many cases specific invoices must be broken down in order to assign them correctly to the different MC3 consumption subcategories. GHG emissions include direct, all upstream indirect, land-use and waste management emissions. Carbon dioxide, methane and nitrous oxide emissions are evaluated and expressed in terms of $\mathrm{CO}_{2}$ equivalents $\left(\mathrm{CO}_{2} \mathrm{eq}\right)$.

\section{Results}

According to $\mathrm{MC} 3$, the total cumulative corporate $\mathrm{CF}$ of HASA in 2012 was $5497.12 \mathrm{t} \mathrm{CO}_{2}$ eq. This result can be classified according to different criteria. The ISO 14064 classification divides total emissions into three categories: Direct $\mathrm{GHG}$ emissions $-2898.23 \mathrm{t} \mathrm{CO}_{2} \mathrm{eq}(52.7 \%$ of total emissions); Energy indirect $\mathrm{GHG}$ emissions -21.00 t $\mathrm{CO}_{2}$ eq $(0.4 \%$ of total emis-

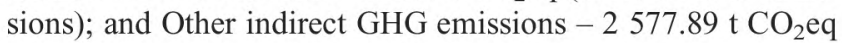


(46.9\% of total emissions). Table 1 shows the inputs and emissions according to this classification and the MC3 category (which is not a main category in the ISO 14064) classification.

Fig. 1 shows the structural composition of the total CF according to MC3 categories. The main source of emissions is the Direct emissions' category, followed by the Materials category (32.0\% of total emissions). In the Direct emissions' category, the consumption of kerosene accounts for the highest contribution (50.4\% of total emissions). In the Materials category, the consumption of transport vehicles has the highest

Table 1. Inputs and carbon footprint of Hispánica de Aviación SA ( $\mathrm{CO}_{2} \mathrm{eq}$ ) by scope and MC3 category

\begin{tabular}{lrr}
\hline Scope/MC3 category (units) & \multicolumn{1}{c}{ Input } & Emission \\
\hline 1. Direct emissions & 34626.98 & \\
1.1. Petrol (L) & 15902.56 & 41.57 \\
1.2. Gasoil (L) & 757975.02 & 2771.09 \\
1.3. Kerosene (L) & & \\
2. Indirect emissions & 110541.33 & 21.00 \\
2.1. Electricity (Kwh) & & \\
3. Other indirect emissions & 745030.96 & 1756.36 \\
3.1. Materials ( $€$ ) & 051443.60 & 471.11 \\
3.2. Services and contracts $(€)$ & 30658.68 & 5.96 \\
3.3. Agricultural and fishing resources $(€)$ & 3325.57 & 8.37 \\
3.4. Forestry resources $(€)$ & 697.44 & 1.71 \\
3.5. Water footprint (m ${ }^{3}$ ) & 41.02 & -14.50 \\
3.6. Land use (ha) & 5.61 & 0.47 \\
3.7. Waste and discharge (t) & & 348.41 \\
3.8. Scope 1 and 2 life cycle emissions & & \\
\hline
\end{tabular}

percentage $(27.7 \%$ of total emissions), followed at a distance by furniture and oils (1.4\% and $1.3 \%)$.

Data from the four management areas are shown in Fig. 2. The total CF from each of General administration and Helitanker maintenance is $995 \mathrm{t} \mathrm{CO}_{2}$ eq ( $18 \%$ of total emissions). Helitanker operations have the highest contribution (3326 t $\mathrm{CO}_{2} \mathrm{eq}$, or $61 \%$ of total emissions), with the lowest being from Airfield and helibase (186 $\mathrm{t} \mathrm{CO}_{2}$ eq, or $3 \%$ of total emissions).

The mean annual flight distance covered by each of the 15 helitankers in operation is $34000 \mathrm{~km}( \pm 11895 \mathrm{~km}$ standard deviation). These results added together for all helitankers totalled a corporate distance of $509995 \mathrm{~km}$ in 2012. Taking into account the total corporate emissions, the average emissions are $10.8 \mathrm{Kg} \mathrm{CO}_{2} \mathrm{eq} \mathrm{km}^{-1}$.

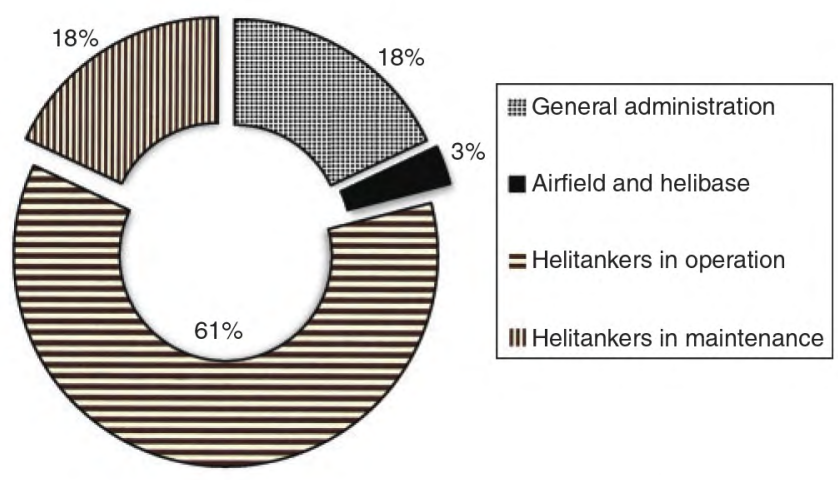

Fig. 2. Structural composition of the carbon footprint of Hispánica de Aviación $S A$ according to management areas.

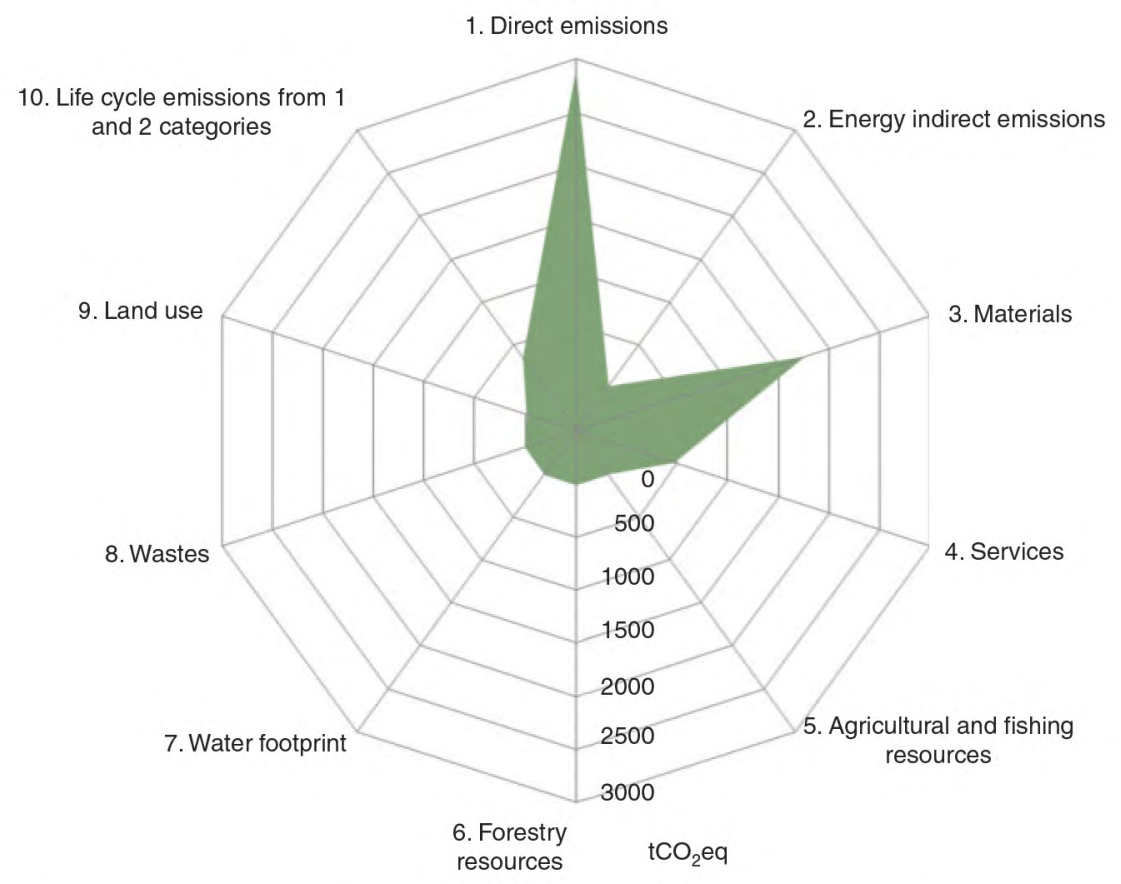

Fig. 1. Structural composition of the carbon footprint of Hispánica de Aviación SA according to consumption categories. 


\section{Discussion}

The relevance of this study is reinforced by the possibility of including new environmental criteria such as CF in sustainable decision making. The results can be analysed from different points of view. First, we evaluate the method's characteristics and influence. Second, we assess the results to understand their implications and to identify future actions.

The strengths and weaknesses of $\mathrm{MC} 3$ have already been outlined by Alvarez et al. (2014). This method offers the chance to work with easy-to-obtain data, and correctly assesses the amount of direct and indirect GHG emissions. In the current study it is worth highlighting one main strength and one weakness. One strength is the complete consideration of other indirect emissions thanks to the use of accounting reports and the use of input-output analysis for CF. Besides, it should be noted that GHG inventories from transport activities are now shifting from direct emissions to the indirect emissions in the upstream supply chain, and those caused by the use and disposal of products (CDP 2013). Helicopter emissions are commonly estimated following IPCC guidelines based only on fuel consumption (Eggleston et al. 2006b). Several examples use these recommendations (FOCA 2009; Linares Bejarano 2011; Merkisz et al. 2012; Grogan 2013). In our experience, these studies fail to account for emissions that should be included; specifically, $49.6 \%$ of total emissions due to all consumption and waste generated from helicopter activity.

The main weakness of the study is that the results for product $\mathrm{CF}$ should be considered as an approximation. Despite our improvements over former studies (FOCA 2009; Linares Bejarano 2011; Merkisz et al. 2012; Grogan 2013), a life cycle phase statement is required for the correct assessment of product $\mathrm{CF}$ (ISO 2013a). Manufacture and disposal life cycle emissions in addition to operation life cycle emissions should be considered in future studies. The reviewed studies show significant differences in consumption depending on the propulsion system (e.g. Grogan 2013), and the helitanker's emissions may vary with the service provided. Each service may produce different emissions based on the fire activity, weather conditions and terrain slopes. The functional unit should therefore be defined in terms of the type and specific service provided by the helitanker.

Our results may be of substantial interest in the field of helitanker services and to helicopter services in general. The CF results provide an analytical basis for the implementation of carbon management plans in HASA. Obviously, reductions in fuel consumption are needed in order to enhance sustainability, and here we should indicate the recommendations of Drozd et al. (2012). Nevertheless, our study allows assessment in categories that are not commonly reported and could produce high effective reductions in total emissions. To give a few examples: (1) materials from maintenance services $(28 \%$ of total emissions) should be evaluated in order to pursue reductions by buying products covered by environmental declarations; (2) gasoil emissions from office boiler consumption (1\% of total emissions) could be reduced by replacing gasoil with natural gas or biomass fuel. Further, the comparison of consumption patterns across management areas and years revealed interesting findings (data not shown) that led to the integration of new schemes for sustainable development in HASA. Finally, in addition to reduction measures, the company could enact compensation measures such as reforestation in permitted areas around the 'El Tiétar' airfield.

Taking into account our results for emissions per $\mathrm{km}$, it may be possible to tradeoff the emissions from helicopter operation against the avoided emissions from wildfire. This simplification does not consider the distance covered by on-site operations (i.e. loading and unloading), as well as other valuable environmental assessments such as the loss of biodiversity and soil erosion, which should not be ignored in a comprehensive view of all environmental effects (Campbell and Tilley 2014). These features (including flood risk) are particularly relevant in the Mediterranean region where effective wildfire suppression may produce important changes (Certini et al. 2011). Therefore, this tradeoff could never be a criterion for decision making, but may give us further insight into the relevance of wildfire emissions and the importance of developing effective techniques for wildfire detection and suppression.

\section{Conclusions}

This study provides further evidence of the value of implementing sustainable indicators in decision making. Our experience should be considered as a pilot study to demonstrate the feasibility and practicality of integrating one of these new sustainable indicators - the CF - in decision making. Despite the focus on the participation of helitankers in wildfire suppression, these criteria may be useful in other more general aspects of helicopter services such as crew transportation and aerial reconnaissance.

In fact, the results may be of considerable interest to the air transport sector in general, and to helicopter services in particular. The differences in the helicopter emissions in the review can be explained by the assumptions of the method. MC3 was easily implemented, and provided a broad field of action in terms of reduction, compensation and communication. Thanks to the wide range of consumption categories, the results can be used as a baseline to measure the effects of future change in policies and technical measures on reducing consumption and materialassociated GHG emissions. Moreover, the assessment using MC3 has raised awareness of the integration of new schemes for sustainable development. Further work is currently ongoing to assess $\mathrm{CF}$ by specific helitanker unit and service.

Our experience indicates the need to reinforce strategies based on the implementation of sustainable indicators such as $\mathrm{CF}$. These new criteria may be useful in making decisions aimed at bringing benefits in sustainable development. Government authorities should be aware of this new capability in aerial firefighting and promote its inclusion in public procurement as a new criterion for award.

\section{Acknowledgements}

This work has been partially funded by the projects AGL2010-16862/FOR from the Spanish government and REMEDINAL3-CM MAE-2719 from the government of the Madrid region. Our warmest gratitude goes to the staff in offices and departments of Hispánica de Aviación and especially to Ms Marina Asunción and Mr Jesús Manuel Fernández. Finally thanks to the Carbonfeel Initiative and Ms Pru Booke-Turner for her linguistic assistance. 


\section{References}

Alvarez S, Rubio A (2015a) Carbon footprint in Green Public Procurement: a case study in the services sector. Journal of Cleaner Production. doi:10.1016/J.JCLEPRO.2015.01.048

Alvarez S, Rubio A (2015b) Compound method based on financial accounts versus process life cycle analysis in product carbon footprint: a comparison using wood pallets. Ecological Indicators 49, 88-94. doi:10.1016/ J.ECOLIND.2014.10.005

Alvarez S, Blanquer M, Rubio A (2014) Carbon footprint using the compound method based on financial accounts. The case of the School of Forestry Engineering, Technical University of Madrid. Journal of Cleaner Production 66, 224-232. doi:10.1016/J.JCLEPRO.2013.11.050

Alvarez S, Sosa M, Rubio A (2015) Product and corporate carbon footprint using the compound method based on financial accounts. The case of Osorio wind farms. Applied Energy 139, 196-204. doi:10.1016/J.APE NERGY.2014.11.039

Ambrosia VG, Buechel SW, Brass JA, Peterson JR, Davies RH, Kane RJ, Spain S (1998) An integration of remote sensing, GIS, and information distribution for wildfire detection and management. Photogrammetric Engineering and Remote Sensing 64(10), 977-985.

Barbot C, Betancor O, Socorro MP, Viecens MF (2014) Trade-offs between environmental regulation and market competition: airlines, emission trading systems and entry deterrence. Transport Policy 33, 65-72. doi:10.1016/J.TRANPOL.2014.02.008

Bonan GB (2008) Forests and climate change: forcings, feedbacks, and the climate benefits of forests. Science 320(5882), 1444-1449. doi:10.1126/ SCIENCE.1155121

Bowman DMJS, Balch JK, Artaxo P, Bond WJ, Carlson JM, Cochrane MA, D'Antonio CM, Defries RS, Doyle JC, Harrison SP, Johnston FH, Keeley JE, Krawchuk MA, Kull CA, Marston JB, Moritz MA, Prentice IC, Roos CI, Scott AC, Swetnam TW, van der Werf GR, Pyne SJ (2009) Fire in the Earth system. Science 324(5926), 481-484. doi:10.1126/SCIENCE. 1163886

Butchart SHM, Walpole M, Collen B, van Strien A, Scharlemann JPW, Almond REA, Baillie JEM, Bomhard B, Brown C, Bruno J, Carpenter KE, Carr GM, Chanson J, Chenery AM, Csirke J, Davidson NC, Dentener F, Foster M, Galli A, Galloway JN, Genovesi P, Gregory RD, Hockings M, Kapos V, Lamarque J-F, Leverington F, Loh J, McGeoch MA, McRae L, Minasyan A, Hernández Morcillo M, Oldfield TEE, Pauly D, Quader S, Revenga C, Sauer JR, Skolnik B, Spear D, Stanwell-Smith D, Stuart SN, Symes A, Tierney M, Tyrrell TD, Vié J-C, Watson R (2010) Global biodiversity: indicators of recent declines. Science 328(5982), 1164-1168. doi: 10.1126/SCIENCE.1187512

Cagiao J, Gómez B, Doménech JL, Mainar SG, Lanza HG (2011) Calculation of the corporate carbon footprint of the cement industry by the application of MC3 methodology. Ecological Indicators 11(6), 1526-1540. doi:10.1016/J.ECOLIND.2011.02.013

Cagiao J, Labella Hidalgo S, Carballo-Penela A, Gómez Meijide B (2012) A new perspective for labeling the carbon footprint against climate change. In 'Global warming - impacts and future perspective' (Ed. DBR Singh) Available at http://cdn.intechopen.com/pdfs-wm/39195. pdf [Verified 9 June 2015].

Campbell ET, Tilley DR (2014) Valuing ecosystem services from Maryland forests using environmental accounting. Ecosystem Services 7, 141-151. doi:10.1016/J.ECOSER.2013.10.003

Carballo-Penela A (2010) "Desarrollo sostenible y ecoetiquetado de bienes y servicios." (AENOR: Madrid)

Carballo-Penela A, Doménech J (2010) Managing the carbon footprint of products: the contribution of the method composed of financial statements (MC3). International Journal of Life Cycle Assessment 15 962-969. doi:10.1007/S11367-010-0230-1

Carballo-Penela A, Doménech JL, García-Negro M do C, SebastiánVillasante C, Rodríguez-Rodríguez G, González-Arenales M (2008)
Análisis comparativo de la huella ecológica de dos empresas del sector pesquero gallego. Observatorio Iberoamericano del Desarrollo Localy la Economía Social 2(4), 1-30. Available at http://www.eumed.net/rev/ oidles/04/pqnvra.htm [Verified 9 June 2015]

Carbonfeel (2013) Bookfeel trial version. Fund. Funciona. Available at http://www.carbonfeel.org/Carbonfeel_2/BookFeel.html [Verified 9 June 2015]

CDP (Carbon Disclosure Project) (2013) Global 500 climate change report 2013. (CDP: London, UK) Available at https://www.cdp.net/cdpresults/ cdp-global-500-climate-change-report-2013.pdf [Verified 9 June 2015]

Certini G, Nocentini C, Knicker H, Arfaioli P, Rumpel C (2011) Wildfire effects on soil organic matter quantity and quality in two fire-prone Mediterranean pine forests. Geoderma 167-168, 148-155. doi:10.1016/ J.GEODERMA.2011.09.005

Commission Decision (2000) 2000/532/EC: Commission Decision of 3 May 2000 replacing Decision 94/3/EC establishing a list of wastes pursuant to Article 1(a) of Council Directive 75/442/EEC on waste and Council Decision 94/904/EC establishing a list of hazardous waste pursuant to Article 1(4) of Council Directive 91/689/EEC on hazardous waste (notified under document number $\mathrm{C}(2000)$ 1147) (Text with EEA relevance). Available at http://eur-lex.europa.eu/smartapi/cgi/sga_doc? smartapi!celexplus!prod!CELEXnumdoc\&numdoc=32000D0532\&lg=en [Verified 9 June 2015]

De la Cruz Leiva JL, Carballo-Penela A, Domenech JL (2011) Enfoques metodológicos para el cálculo de la Huella de Carbono. Obs. la Sostenibilidad España. Available at http://www.carbonfeel.org/Carbonfeel 2/Bitacora/Entradas/2011/9/15_Informe_Enfoques_metodologicos_para_ el_caclulo_de_la_Huella_de_Carbono_del_Isntituo_de_la_Sostenibilidad en_Espana_files/Informe\%20OSE.pdf [Verified 9 June 2015]

Doménech JL (2007) ‘Huella Ecológica y Desarrollo Sostenible.' (AENOR: Madrid)

Drozd GT, Miracolo MA, Presto AA, Lipsky EM, Riemer DD, Corporan E, Robinson AL (2012) Particulate matter and organic vapor emissions from a helicopter engine operating on petroleum and Fischer-Tropsch fuels. Energy \& Fuels 26(8), 4756-4766. doi:10.1021/EF300651T

Eggleston S, Buendia L, Miwa K, Ngara T, Tanabe K (Eds) (2006a) '2006 IPCC Guidelines for National Greenhouse Gas Inventories. Volume 4: Agriculture, forestry and other land use.' (Institute for Global Environmental Strategies (GES): Hayama, Japan)

Eggleston S, Buendia L, Miwa K, Ngara T, Tanabe K (2006b) '2006 IPCC Guidelines for National Greenhouse Gas Inventories. Volume 2: Energy.' (Eds NT Eggleston, TK Eggleston, HS, L Buendia, K Miwa) (Institute for Global Environmental Strategies (GES): Hayama, Japan)

Fischlin A, Midgley GF, Price JT, Leemans R, Gopal B, Turley C, Rounsevell MDA, Dube OP, Tarazona J, Velichko AA (2007) Impacts, adaptation and vulnerability. Contribution of Working Group II to 'IPCC Fourth Assessment Report on Climate Change 2007.' (Eds ML Parry, OF Canziani, JP Palutikof, PJ Van der Linden, CE Hanson)(Cambridge University Press: Cambridge, UK) Available at http://www.ipcc.ch/pdf/ assessment-report/ar4/wg2/ar4-wg2-chapter4.pdf [Verified 9 June 2015]

Flannigan MD, Amiro BD, Logan KA, Stocks BJ, Wotton BM (2006) Forest fires and climate change in the 21 st century. Mitigation and Adaptation Strategies for Global Change 11(4), 847-859. doi:10.1007/ S11027-005-9020-7

FOCA (Federal Office of Civil Aviation) (2009) 0/3/33/33-05-020 Guidance on the determination of helicopter emissions. (FOCA: Bern).

Greenhalgh S, Ranganathan J, Sundin H (Eds) (2010) 'The GHG protocol for project accounting.' (World Resources Institute and World Business Council for Sustainable Development: Washington, DC)

Grigel J (1974) Role of the helitanker in forest fire control. Available at http://nofc.cfs.nrcan.gc.ca/bookstore_pdfs/11748.pdf [Verified 9 June 2015] 
Grogan P (2013) $\mathrm{CO}_{2}$ emissions calculator for travel including small fixedwing and helicopter aircraft - generic.xls. Available at https://www. google.es/url? sa=t\&rct=j\&q=\&esrc=s\&source=web\&cd=1\&cad=rja\& uact $=8 \&$ ved $=0$ CDEQFjAA\&url=http://post.queensu.ca $/ \sim$ groganp $/ \mathrm{CO} 2 \%$ 20 emissions $\% 20$ calculator $\% 20$ for $\% 20$ travel $\% 20$ including $\% 20$ small $\%$ 20 fixed-wing $\% 20$ and $\% 20$ helicopter $\% 20$ aircraft $\% 20-\% 20$ generic.xls\& ei=npcyU6e_BMiY0AXj3oHoCw\&usg=AFQjCNFKJa9qE-u8YUGDYo_ ekw4jU5GViw\&sig2=1Gi0khmyoucv4F0eOs2-2Q\&bvm=bv.63738703,d. d2k [Verified 9 June 2015]

ISO (International Organization for Standardization) (2006) ISO 14064 1:2006 Greenhouse gases - Part 1: specification with guidance at the organization level for quantification and reporting of greenhouse gas emissions and removals. Available at http://www.iso.org/iso/ catalogue_detail?csnumber $=38381$ [Verified 9 June 2015]

ISO (International Organization for Standardization) (2013a) ISO/TS 14067:2013 Greenhouse gases - Carbon footprint of products Requirements and guidelines for quantification and communication. (ISO: Geneva, Switzerland.)

ISO (International Organization for Standardization) (2013b) ISO/TR 14069:2013 Greenhouse gases - Quantification and reporting of greenhouse gas emissions for organizations - Guidance for the application of ISO 14064-1. (ISO: Geneva, Switzerland)

Körner C (2005) Tropical forests dynamics in response to a $\mathrm{CO}_{2}$-rich atmosphere. In 'Tropical forests and global atmospheric change.' (Eds Y Malhi, O Phillips) pp. 67-73. (Oxford University Press: Oxford, UK)

Linares Bejarano CA (2011) Environmental impact assessment of the operation of conventional helicopters at mission level. Thesis, Cranfield University, UK. Available at https://dspace.lib.cranfield.ac.uk/handle/ 1826/7167 [Verified 16 June 2015]

Majeau-Bettez G, Strømman AH, Hertwich EG (2011) Evaluation of process- and input-output-based life cycle inventory data with regard to truncation and aggregation issues. Environmental Science \& Technology 45(23), 10 170-10 177. doi:10.1021/ES201308X

Meigs GW, Turner DP, Ritts WD, Yang Z, Law BE (2011) Landscapescale simulation of heterogeneous fire effects on pyrogenic carbon emissions, tree mortality, and net ecosystem production. Ecosystems 14(5), 758-775. doi:10.1007/S10021-011-9444-8

Merkisz J, Markowski J, Pielecha J, Pielecha I (2012) Exhaust emissions from the PZL SW-4 PUSZCZYK helicopter based on the measurements of the concentrations of exhaust components in the exhaust gases during a pre-flight test. Journal of Polish CIMAC 7(2), 123-130.

Miller JR, Morton LW, Engle DM, Debinski DM, Harr RN (2012) Nature reserves as catalysts for landscape change. Frontiers in Ecology and the Environment 10(3), 144-152. doi:10.1890/100227

Miyoshi C (2014) Assessing the equity impact of the European Union Emission Trading Scheme on an African airline. Transport Policy 33, 56-64. doi:10.1016/J.TRANPOL.2014.02.010

Moore P, Hardesty J, Kelleher S, Maginnis S, Myers R (2003) Forests and wildfires: fixing the future by avoiding the past. Paper presented at the 'XII World Forestry Congress', 21-28 September 2003, Quebec, CA. Available at http://www.fao.org/docrep/article/wfc/xii/0829-b3.htm [Verified 9 June 2015]
Pan Y, Birdsey RA, Fang J, Houghton R, Kauppi PE, Kurz WA, Phillips OL, Shvidenko A, Lewis SL, Canadell JG, Ciais P, Jackson RB, Pacala SW, McGuire AD, Piao S, Rautiainen A, Sitch S, Hayes D (2011) A large and persistent carbon sink in the world's forests. Science 333(6045), 988-993. doi:10.1126/SCIENCE. 1201609

Peters GP (2010) Carbon footprints and embodied carbon at multiple scales. Current Opinion in Environmental Sustainability 2(4), 245-250. doi:10.1016/J.COSUST.2010.05.004

Peters GP, Weber CL, Guan D, Hubacek K (2007) China's growing $\mathrm{CO}_{2}$ emissions: a race between increasing consumption and efficiency gains. Environmental Science \& Technology 41(17), 5939-5944. doi:10.1021/ ES070108F

Ricondo \& Associates (2008) Appendix F. Air quality analysis. In 'Final environmental assessment for the proposed South Nevada Regional Heliport', p. 50. (Clark County Department of Aviation: Clark County, NV) Available at http://www.ricondoprojects.com/Heliport/F_AQ.pdf. [Verified 9 June 2015]

Roca LC, Searcy C (2012) An analysis of indicators disclosed in corporate sustainability reports. Journal of Cleaner Production 20(1), 103-118. doi:10.1016/J.JCLEPRO.2011.08.002

Solomon S, Qin D, Manning M, Chen Z, Marquis M, Averyt KB, Tignor M, Miller HL (Eds) (2007) 'Contribution of Working Group I to the Fourth Assessment Report of the Intergovernmental Panel on Climate Change, 2007: The physical science basis.' (Cambridge University Press: Cambridge, UK). Available at http://www.ipcc.ch/publications_and data/ar4/wgl/en/contents.html [Verified 9 June 2015]

Sommers WT, Loehman RA, Hardy CC (2014) Wildland fire emissions, carbon, and climate: science overview and knowledge needs. Forest Ecology and Management 317, 1-8. doi:10.1016/J.FORECO.2013. 12.014

Stocker TF, Qin D, Plattner GK, Tignor M, Allen SK, Boschung J, Nauels A, Xia Y, Bex V, Midgley PM (Eds) (2013) 'Climate Change 2013: The physical science basis. Summary for policymakers.' Contribution of Working Group I to the IPCC Fifth Assessment Report on Climate Change 2013. (Cambridge University Press: Cambridge, UK)

Suh S, Huppes G (2005) Methods for life cycle inventory of a product. Journal of Cleaner Production 13(7), 687-697. doi:10.1016/J.JCLE PRO.2003.04.001

Suh S, Lippiatt BC (2012) Framework for hybrid life cycle inventory databases: a case study on the Building for Environmental and Economic Sustainability (BEES) database. International Journal of Life Cycle Assessment 17(5), 604-612. doi:10.1007/S11367-012-0393-Z

Wiedmann T, Minx J (2008) A definition of 'carbon footprint.' In 'Ecological Economics Research Trends', (Ed. CC Pertsova) pp. 1-11. (Nova Science Publishers: Hauppauge, NY) Available at https://www.novapublishers.com/catalog/product_info.php?products_id=5999 [Verified 9 June 2015]

Wiedmann T, Wilting HC, Lenzen M, Lutter S, Palm V (2011) Quo Vadis MRIO? Methodological, data and institutional requirements for multiregion input-output analysis. Ecological Economics 70(11), 1937-1945. doi: 10.1016/J.ECOLECON.2011.06.014 